\title{
A globális karriermenedzsment funkciói ${ }^{1}$
}

\author{
SZONDI RÉKA ${ }^{2}$
}

\begin{abstract}
ABSZTRAKT
A vállalatok hosszútávú stratégiai céljai közt szerepel a versenyképesség fenntartása. A materiális és immateriális javak mellett a humán tőke értéke folyamatosan növekszik, köszönhetöen a munkaeröpiaci változásoknak. A lojális, speciális szaktudású munkavállaló nagymértékben hozzájárul a szervezeti siker eléréséhez a kompetenciák, tapasztalatok és készségek révén. A multinacionális cégek karriermenedzsment rendszerét vonzóbbá teszi a nemzetközi kiküldetések lehetőségének megléte, ami egy nagyon összetett, komplex tervezést igénylö folyamat. Ez a rendszer globálisnak tekinthető több okból is: az országokon átívelő jellege miatt, a munkavállalóknak nyújtott nemzetközi tapasztalatszerzés okán és végső soron a sikeres folyamat részeként azért, mert a munkavállaló globális színtéren valósít meg egyéni karriert.

A globális karriermenedzsment kiépítése így számos HR funkciót foglal magába. Hangsúlyt kell fektetni többek között a megfelelő munkavállalók megtalálására, kiválasztására, beillesztésére, a mentorálására, a teljesítményértékelés során alkalmazott módszerek alkalmazására és az értékelők körére, a megfelelő rendszerességú és módú visszajelzésre, a motiváció elérésére és fenntartására, a kompetenciák fejlesztésére és a mentálhigiéné egyensúlyának fenntartására.
\end{abstract}

KULCSSZAVAK: humán tőke, globális karrier, karriermenedzsment, HR funkciók, teljesítmény, megtartás, kompetencia

\section{ABSTRACT}

\section{Functions of global career management}

Maintaining competitiveness is one of the long-term strategic goals for companies. Beside tangible and intangible assets, the value of human capital is continuously growing, due to changes in the labour market. A loyal, highly skilled employee makes a significant contribution to organizational success through competencies, experience, and skills. The career management system of multinational companies became more attractive by the possibility of international assignments, which is a very complicated process requiring complex planning. This system is

${ }^{1}$ EFOP3.6.3-VEKOP-16-2017-00007- „Tehetségből fiatal kutató” - A kutatói életpályát támogató tevékenységek a felsőoktatásban projekt támogatásával készült.

${ }^{2}$ Debreceni Egyetem Ihrig Károly Gazdálkodás- és Szervezéstudományok Doktori Iskola, szondi.reka@econ.unideb.hu 


\section{TEMATIKUS TANULMÁNYOK - Emberierőforrás-menedzsment napjainkban}

considered global for several reasons: its transnational nature, international experience gained by the employees and the achievable career on a global scale for the individual (as a part of a successful process).

Creating a global career management system thus involves a number of HR functions. Emphasis should be placed on finding suitable employees, selecting, onboarding, mentoring, on methods and the evaluators in the performance appraisal process, providing feedback on a regular basis and in an appropriate manner, achieving and maintaining motivation, developing competencies and supporting the balance in mental health.

KEYWORDS: human capital, global career, career management, HR functions, performance, retainment, competence

\section{Bevezetés}

A kiválóan teljesítő, lojális és tehetséges munkavállalók iránti szükséglet megtöbbszöröződött, mind hazai, mind globális szinten. A munkavállalók bevonzásánál és későbbi megtartásánál is eszköz lehet a jól kiépített szervezeti karriermenedzsment rendszer, mint a vállalati brand része. A nemzetközi tapasztalat megszerzése alatt nem csak a munkavállaló szembesül kihívásokkal, hanem a vállalat és a HR is. A folyamat összetettsége előrevetíti a hibalehetőségek nagy számát, ám a részletekre való odafigyeléssel, a tervezési aspektusok kiszélesítésével az érintett funkciók öszszehangolt működése megvalósíthatóvá válik.

Mind a karriertervezés célja, mind a tartalma változáson ment keresztül. A kezdetekben az egyéni igények, később viszont a szervezeti igények kerültek előtérbe. A karriergondozás és a karrierfejlesztés a 60-as évek elején kezdett kibontakozni a fejlett piacgazdaságokban. A 80-as években a szervezeti célok elérése mutatott dominanciát, tekintve az egyre inkább kiélesedő világpiaci versenyt. Az egyoldalú hangsúlyozást váltotta fel a két oldal céljainak és érdekeinek összehangolása a 90-es években, amikor is az egyensúly megteremtése, a karriertervezés kétoldalúsága humánstratégiai célként jelent meg. A vállalatok elkezdték felismerni, hogy a munkaerő értékének emelkedése és a munkaerőpiaci változások miatt, érdemes foglalkozni a munkaerő-állomány megtartásával. A megtartáshoz járul hozzá a dolgozók egyéni karrierigényeire való odafigyelés, a motiválásukra és ösztönzésükbe fektetett idő- és pénzbeli eszközök, melyek segítségével biztosítható az egyéni képességek és az egyéni tudáspotenciál kihasználása, ami a szervezeti teljesítmény fenntartásának egyik alapvető feltétele (Koncz 2013). A szervezet által kínált karrierlehetőség kapcsolatban áll a munkaerő toborzásával, bevonzásával, beillesztésével, fejlesztésével, megtartásával egyaránt. A munkavállalói karrier gondozásával a munkavállaló tudását is növeli és beépíti a szervezet, ami az információk megőrzésében is nagy szerepet játszik. A karriermenedzsmentre mint HR funkcióra való építkezés befektetésként is értelmezhető. Mindez feltételezte egy olyan karrierfejlesztési rendszer kiala- 


\section{TEMATIKUS TANULMÁNYOK - Emberierőforrás-menedzsment napjainkban}

kítását és működtetését, amelyben az egyéni megelégedettség és a teljesítmény, valamint a szervezet stratégiai céljainak megvalósulása a szervezeti siker tartóoszlopaivá léptek elő.

\section{A humánerőforrás-menedzsment funkcióinak megjelenése}

A szervezet különböző erőforrásai önmagukban nem ismerhetők el stratégiai versenyelőnyként, csak abban az esetben, ha egy rendszerbe foglalva, egy folyamat részeként gazdálkodnak velük (Veresné 2017). Ezek az erőforrások lehetnek emberi, tárgyi és a szervezeti tőkében mért összetevők, melyek megadják a szervezet értékét. A vállalati méretek növekedésével és a munkaerőpiacon kialakult helyzet miatt a szervezetek emberierőforrás-menedzsmentje a versenyképesség megőrzésének tekintetében kulcsfaktorrá vált (Poór et al. 2018). A munkavállalók értéket jelentenek, a képzésekre, fejlesztésre fordított idő és pénz befektetésnek minősül, így előtérbe kerül a vezető és a HR szakemberek szerepe abban, hogy a kulcskompetenciákat, az igényelt tudást felismerjék és megfelelő szintre emeljék. A vezetői munkakörökben Klein (2012) az eredményorientáltságot, kommunikációt, együttműködést, kockázatvállalást, a közös munkavégzés képességét és a felelősséget tartja a legfontosabbaknak. A nagy potenciállal rendelkező tehetséges jelölteket a szervezetbe vonzani nem egyszerű feladat. Közvetíteni kell az értékeket, célokat, látásmódot, ezáltal is segítve a már foglalkoztatott és a toborzás célcsoportjába kerülő személyek egyéni céljainak és értékrendszerének az összekapcsolását a vállalati oldallal (Erdei et al. 2017).

A humánerőforrás-menedzsment funkcióinak kialakulása egy hosszú folyamat eredménye. Ezek a funkciók folyamatosan bővülnek, a szervezeteknek, a vezetői szintnek, a HR-nek mindig reagálnia kell a globalizáció és a megváltozott munkaerőpiac változásaira, így ez a folyamat talán soha nem tekinthető majd lezártnak és befejezettnek.

A klasszikus vezetési iskolák képviselői közt meg kell említeni Taylort, aki alapvetően négy vezetési funkciót különít el (1911). Munkássága alatt ezekre a funkciókra (technológus, karbantartó, normás, minőségellenőrző) önálló vezetői munkaköröket is alkotott. Fayol (1916) rendszerezése alapján szisztematikusan halad, meghatároz vezetési feladatokat és ezek egymásra épülését, ám a döntési jogkört nem jeleníti meg a feladatok között, abból az okból, hogy a döntést tulajdonosi kompetenciaként tartották számon a kor gyakorlatában (Berde 2015) (1. táblázat). 


\section{TEMATIKUS TANULMÁNYOK - Emberierőforrás-menedzsment napjainkban}

1. táblázat. A Taylor által megalkotott vezetői funkciók és a Fayol-i vezetési feladatok

\begin{tabular}{|c|c|}
\hline Taylor & Fayol \\
\hline Technológus & Tervezés \\
\hline Karbantartó & Szervezés \\
\hline Normás & Közvetlen irányítás \\
\hline \multirow{2}{*}{ Minőség-ellenőrző } & Koordinálás \\
\hline & Ellenőrzés \\
\hline
\end{tabular}

Forrás: Berde (2015) alapján saját szerkesztés

Taylor a tudományos vezetés alapelveiről a következőket fogalmazta meg (1911):

1. A vezetésnek a munkavégzés minden elemét szabályoznia kell tudományos alapon.

2. A vezetőknek a munka szempontjából legmegfelelőbbnek tartott alkalmazottakat tudományos alapon kell kiválasztaniuk.

3. A vezetők és beosztottak egyetértésben dolgozzanak egymással.

4. A munka és a felelősség megosztása fontos a vezetők és a végrehajtók között.

Ez alapján elmondható, hogy Taylor számára a vezetés és szervezés feladata vezetők számára leosztott szerep, míg az alkalmazottak nem kerülnek bevonásra ezeken a területeken (Gulyás - Turcsányi 2018). Taylor, Fayol és Weber nevéhez köthetően az 1900-as évek elejétől elindult a HR funkciók fejlődése, innentől fogalmazódott meg a fizikai munkásokkal kapcsolatos szerepkör, az ő vezetésük és irányításuk a termelékenység növelése érdekében. Számos hagyományos funkcióra ismerhetünk, pl. az időnorma alapján meghatározott teljesítményértékelés, a motiváció, kiválasztás, fejlesztés és a lojalitás fontossága (Dajnoki - Héder 2017). A személyzeti menedzsmentnek tulajdonított adminisztratív feladatok ugyan később alakultak ki, de az emberi erőforrás irányítása egyre több teret nyert a szervezeti irányításban.

\section{Karriermenedzsment a szervezetekben}

A menedzsmentfunkciókkal foglalkozó szakirodalom sok esetben különbözik a felsorolás, tipizálás kapcsán. A hagyományos menedzsmentfunkciókra épülve számos alkalommal bővültek a területek, és napjainkban sem tekinthető lezártnak ez a folyamat. A humánerőforrás-gazdálkodás komplex és összetett tevékenység (Szabó Berde 2007), melyben az egyes területek hatással vannak egymásra. A rendszer érzékenysége miatt, egyes hiányosságok vagy nem jól működő gyakorlatok problémát okozhatnak a szervezet egészében, ami a munkavállalók menedzselését illeti. A tevékenységterületek között megjelenik a megtervezendő munkaerői létszám, a munkakörök kialakítása, a legmegfelelőbb ember megtalálása a munkakör betöltéséhez, 


\section{TEMATIKUS TANULMÁNYOK - Emberierőforrás-menedzsment napjainkban}

dolgozói motiváció, teljesítmény értékelése, továbbképzési lehetőségek megléte, munkavégzés feltételeinek biztonsága. Az emberierőforrás-gazdálkodás nevezhető a humánpolitikai tervben leírt célok megvalósítására létrehozott eszközként, amelynek központi eleme a munkaerő-ellátás lehető leggazdaságosabb szervezése és a rendelkezésre álló munkaerő hatékony felhasználása (Hajós - Gősi 2008). Az emberi erőforrások képzése és fejlesztése szinte mindig központi szerepkört töltött be a szervezetekben, ezért nem meglepő, hogy a karriermenedzsment, a karriertervezési rendszerek, valamint a tudásmenedzsment is önálló funkciókká léptek elő. Minden szerző más-más tevékenységterületekre helyezi a hangsúlyt, a legtöbbször használt funkciók feltüntetése Dajnoki (2014) gyűjtése és kiegészítése (esélyegyenlőségi emberierőforrás-menedzsment) alapján az 1. ábrán szerepel.

1. ábra. A humánerőforrás-menedzsment területei

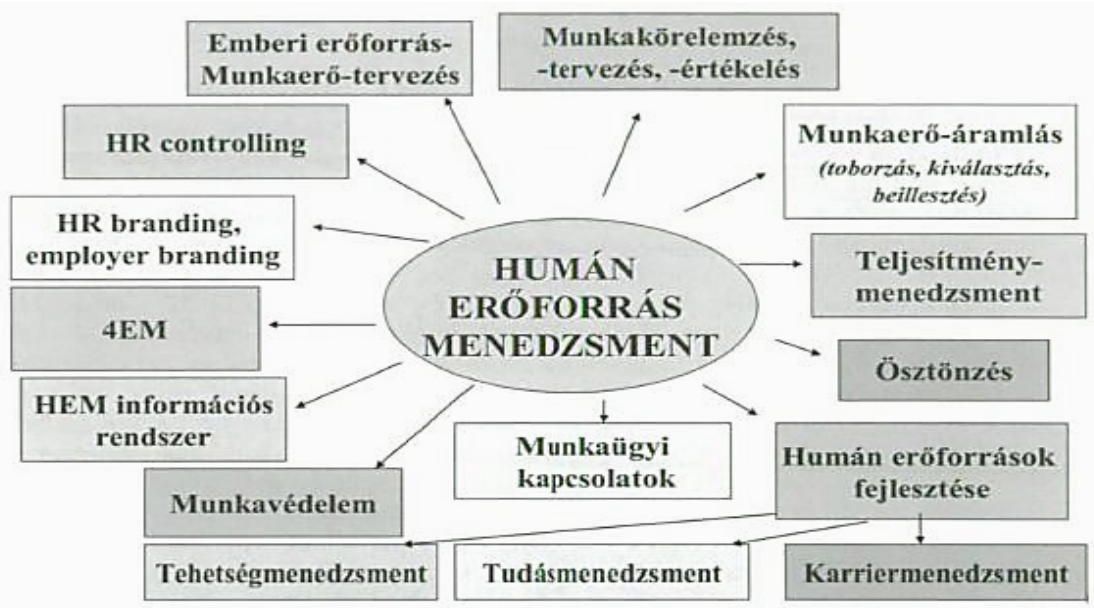

Forrás: Dajnoki 2014: 24

A funkciók csoportosításában a humán erőforrások fejlesztése három részre tagolható tovább. Ezek a területek a tehetségmenedzsment, tudásmenedzsment és a karriermenedzsment. A karriermenedzsment így szoros kapcsolatot mutat a fejlesztéssel, és szinte mellérendelt kapcsolatként értelmezhető a tehetség- és a tudásmenedzsment jelenléte is.

Dajnoki - Héder (2017) modelljében (2. ábra) a HR új kihívásait feltüntetve, a funkciók közötti átmenetet, a HR stratégiai szerepének előlépését mutatja be. A hagyományos funkciók a változó üzleti környezetre reagálva fejlődésen mentek keresztül, ami számos új terület és gyakorlat létrejöttét és tudatos alkalmazását tette szükségessé. A megtartásmenedzsment az egyik legnagyobb kihívást jelentő területté 


\section{TEMATIKUS TANULMÁNYOK - Emberierőforrás-menedzsment napjainkban}

lépett elő, melyre majdnem minden más funkció hatással van, akár közvetve, akár közvetlenül.

2. ábra. A hagyományos humánerőforrás-funkciók fejlődése

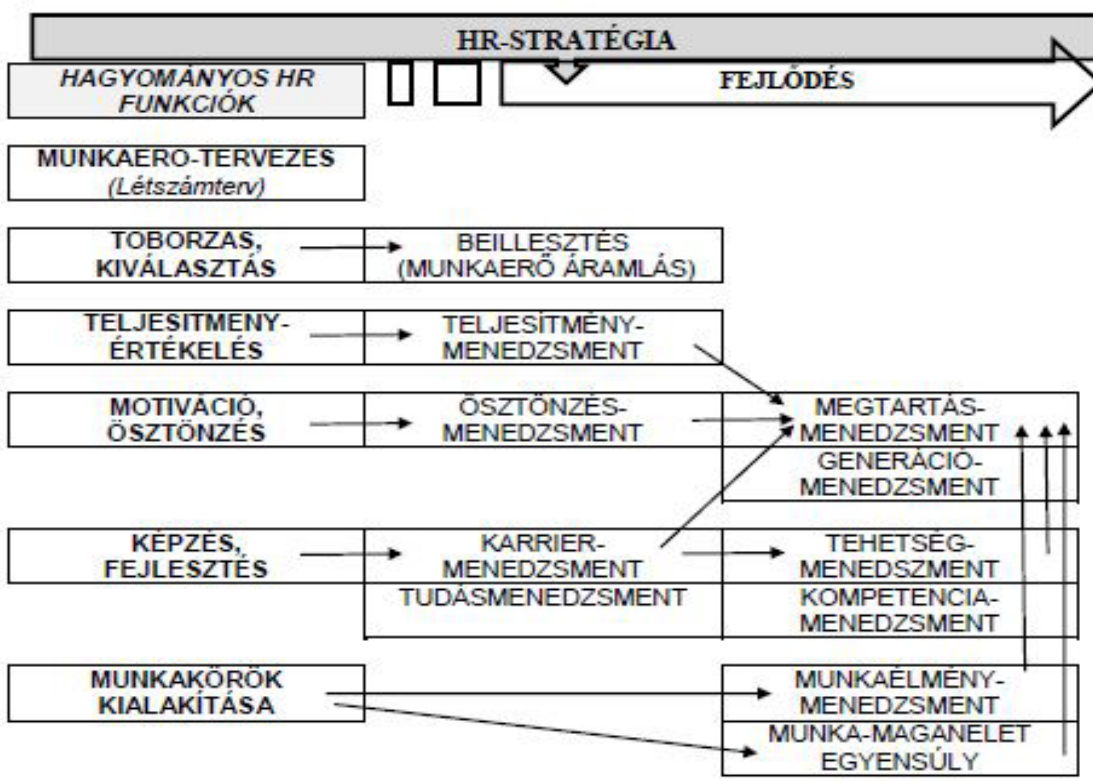

MUNKAVEDELEM $\longrightarrow$ EGESZSÉGMEGÖRZES

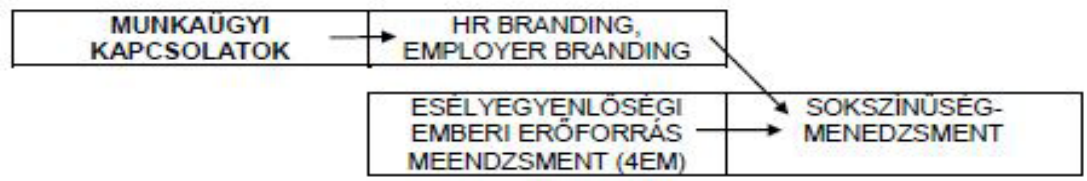

MEENDZSMENT (4EM)

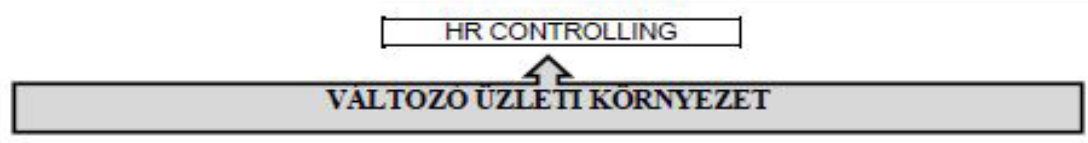

Forrás: Dajnoki - Héder 2017: 85

Az újként megjelenő funkciók beépültek a stratégiába is, így alkotva integrált rendszert. A munkaélmény, a munka-magánélet egyensúlya, a karrier- és tehetségmenedzsment, a kompetenciákkal és a tudással kiegészülve, a munkahelyen egyszerre jelenlévő különböző generációk vezetése mind hozzájárul a szervezeti kötődés, lojalitás létrejöttéhez. 


\section{TEMATIKUS TANULMÁNYOK - Emberierőforrás-menedzsment napjainkban}

A karriermenedzsment-rendszer mint a funkciók egyike egyre növekvő jelentőséggel bír. Ám a szakirodalom részletezi, hogy nem mindenki akar feltétlenül vezetői beosztásba kerülni és nem is mindenki alkalmas rá. A karrier értelmezése és az elérni kívánt célok egyénenként eltérőek lehetnek. Napjainkban elterjedt jelenség a jobhopping, ami a munkavállalók egyik munkahelytől a másikig történő ugrálását jelenti, más szavakkal élve, a gyakori - átlagosan egy- és másfél évente - történő munkahelyváltás (Mándi 2018). A munkavállalók egyre gyakrabban néznek új munkahely után, de nem kizárólagosan azért, mert nem szeretnének tartósan egy munkaadónak dolgozni. Ezzel szemben arra irányul a törekvés, hogy a lehetőségekhez mérten minél tovább maradjanak egy vállalatnál, ott tudjanak fejlődni, sikereket érjenek el (Clarke 2013). A sikeresség és az előrelépés érzése alapvető igények, amivel számolnia kell a vállalatnak, ha célja a munkaerő hosszútávú megtartása. A szervezeti karriergondozás során a munkavállalókat támogatják egyéni karrierfejlesztési törekvéseikben, kellő figyelemmel a vállalati célokra, a két oldal összehangolásával megalkotva a karriermenedzselési rendszert (Baruch 2006). A karriermenedzsment gyakorlati alkalmazásának főbb szereplői az alábbiak lehetnek:

- A munkavállalók: ideáltipikus helyzetben van meghatározott karriercéljuk és megfelelő önismeretük. A célok elérése érdekében elvárásoknak felelnek meg, keresik a fejlődési lehetőségeket.

- A HR részlegén dolgozók: ők felelősek a karriermenedzsment-rendszer kidolgozásáért és fejlesztéséért. Megállapítják a karrierszűrőket, karrierlépcsőket, előmeneteli alapelveket, és biztosítják a megvalósításnál megjelenő költségeket, erőforrásokat.

- A közvetlen felettes: szerepe kétirányú, egyrészt tapasztalja a munkavállaló által nyújtott teljesítményt és ismerettel rendelkezik a szervezeten belüli lehetőségekkel. Akár először konzultálhat az alkalmazottakkal és segítheti őket céljaikban, lévén felettesként ismeri a munkavégzésüket (Poór et al. 2017).

Noha nem rendelkezik minden szervezet karriermenedzselési tervvel, a „karriergondozási tevékenység" nem elkerülhető. Minden belépő munkavállaló életpályáját nyomon követjük komplex karriergondozási rendszer hiányában is. Az előléptetések során vagy a szenioritás, vagy a szakértelem elvét követve soroljuk az egyént új pozícióba, vagy kialakítunk formális, informális előmeneteli utakat (Dessler - Cole 2008). Egy 2004-ben történt „Legjobb munkahely” felmérésben a megkérdezett hazai vállalatok 61\%-a alkalmazott formális karriergondozási programot, ebben azonban mindössze a munkavállalók 9,4\%-a szerepelt (Marton, 2004). A tehetségmenedzsment programok többnyire karriermenedzsment programnak is tekinthetők Koncz (2013) alapján. Bokor és szerzőtársai (2006a) vizsgálatában rendkívül kevés szervezet rendelkezett igazán komplex, kétoldalú, az összes munkavállalót magába foglaló rendszerrel. A DGS Global 2009-es eredményei is hasonló adatokat tükröznek: a 651 szervezetet felölelő minta 6,9\%-a foglalkozik tudatos utánpótlás-terve- 


\section{TEMATIKUS TANULMÁNYOK - Emberierőforrás-menedzsment napjainkban}

zéssel és karriermenedzsmenttel, ami többségében csak néhány kiemelt munkatársra vonatkozik.

Az AON Hewitt tanácsadó vállalat (2010) kutatásában 193 munkaadóval rendelkező mintájában vizsgálta a szervezeti karriermenedzsment gyakorlati oldalát. A megkérdezettek 77\%-a szerint a karriermenedzsment sokkal nagyobb térnyerésen ment keresztül, mint az azt megelőzó években, míg 83\%-uk szerint a karrierlehetőségek biztosítása az egyik alapvető szükségesség, ha a munkavállalók megtartása a cél. A karriermenedzsment-rendszer szoros összefüggést mutat a többi funkcióval, amit szintén alátámaszt az a tény, hogy a megkérdezett munkáltatók szervezetének 85\%-ánál a karriermenedzsment kapcsolódik a teljesítménymenedzsment-rendszerhez.

Koncz (2013) összegzése szerint a szervezeti karriergondozás a szervezet számára releváns és értékes munkaerő megszerzése, megtartása, motiválása és fejlesztése érdekében működik (3. ábra). „A komplex szervezeti karriergondozás funkciói tehát azonosak az emberierőforrás-gazdálkodás funkcióival, de azzal a minőségi különbséggel, hogy az egyes funkciók karrier szempontból átrendeződnek." (Koncz 2013: 113) A szervezeti karriergondozás, a stratégia, tervezés, megvalósítás, értékelés folyamatának négy lépése révén válhat hatékonnyá.

3. ábra. A karriergondozás funkciórendszere

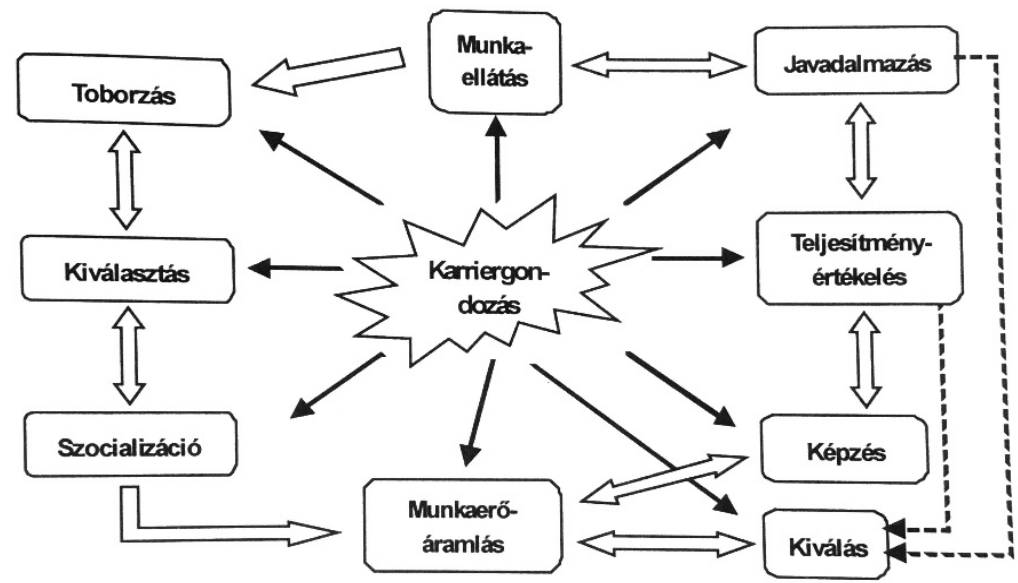

MEGJEGYZÉs: $A \longrightarrow$ jel a funkciók közötti összefüggés, a $\longrightarrow$ jel a karriergondozás és más funkciók közötti összefüggés jelölésére szolgál.

Forrás: Koncz 2013: 113 


\section{TEMATIKUS TANULMÁNYOK - Emberierőforrás-menedzsment napjainkban}

Nem állapítható meg egységes stratégia a szervezeti előmenetelre vonatkozóan, vállalatonként eltérő karrierrendszerek alakulnak ki az erőforrások, külső és belső tényezők alapján. Bokor és szerzőtársai (2006 b) kutatásai eredményeképpen három csoportba különíti el a karrier menedzselését.

Az első az integrált szemlélet, amikor a munkavállalók egészére kiterjed a rendszerszemléletű egyéni és szervezeti karriermenedzsment. A második a fókuszáló szemlélet, a különböző szakterületek közül (utódlástervezés, megtartás, fejlesztés) mindig más mutat különbséget a többivel szemben, nem egyforma fontosságúak. A harmadik az ad hoc vagy informális nézőpont, amelyben nem beszélhetünk formális értelemben vett karrierrendszerről (főleg kisebb méretű vállalkozásoknál), a karriergondozás felbukkanása más funkcióknál bevonva jelenik meg inkább, pl. a teljesítményértékelés esetében.

A karriermenedzsment-folyamatokban alkalmazott eszközök között számos különbséget tehetünk. Ilyen eszközök a képzés, fejlesztés, mentorprogram, teljesítményértékelés. Továbbá ide tartozik még a karrierkonzultáció, formális karriertervek, projektfeladatok, rotáció, munkakör-gazdagítás és a külföldi kiküldetés lehetősége is (Lewis - Arnold 2012). A munkavállaló motivációja elsősorban a pszichológiai belső elégedettség megélése, ritkábban kerül a hangsúly a külső materiális tényezőkre (pl. a fizetés), a hatalomra, ami a munkakörrel jár vagy a vezetőség értékelésére (Batizi 2017). Guan és szerzőtársai (2015) kutatásában pozitív korrelációt talált a munkavállalói alkalmazkodóképesség, a szervezeti karriermenedzsment és a munkahelyi elégedettség között, mely alapján a dolgozók, akik nagyobb mértékben alkalmazkodtak a karrierjük elvárásaihoz, pozitívabban álltak a szervezeti célok és elképzelések kapcsán jelentkező feladatok elé. Fajcikova és munkatársai (2018) tanulmányában vizsgálták a tehetséggondozás összefüggését más funkciókkal (több mint 300 szervezet alapján, melynek egyharmada minimum 250 főt foglalkoztat), és a megkérdezettek alapján megállapították, hogy a karriermenedzsment a képzéssel és fejlesztéssel, a munkaerő biztosításával, továbbá a teljesítményértékeléssel és ösztönzéssel mutat szoros kapcsolatot.

\section{A globális karrier értelmezésében felmerülő fő funkciók}

A szervezetek stratégiáinak alkalmazkodni kell a munkaerőpiacon tapasztalt változásokhoz és az újabb generációkkal megjelenő munkavállalói elvárásokhoz is. A munkavállaló megtartása, vállalathoz vonzása egy dolog, de emellett hangsúlyozni kell az igazán elkötelezetté válást is, amelyben a lojalitás magas teljesítménnyel párosul (Istók 2019). A motivációs eszköztárat a munkavállalóra kell szabni, az egyéni igények előtérbe kerülnek (Krajcsák 2018). Az elkötelezettség összefügg a motiváltsággal, ezt az elkötelezettséget lehet javítani egy olyan hosszútávú karrier lehetőségével (nemzetközi kiküldetés), ami a munkavállalói igényeknek megfelelő, ezáltal a 


\section{TEMATIKUS TANULMÁNYOK - Emberierőforrás-menedzsment napjainkban}

belső intrinzik motivációval növekszik a szervezethez kapcsolt lojalitás is, és a kiküldetés sikeressége is valószínűsíthető.

A globális karrier meghatározásában megjelenik a multinacionális vállalatok elterjedése és a globalizációs hullám, melyek a globális színtéren alkalmazható tudás meglétére fókuszálnak a nemzetközi piacokon működő cégek által. Vállalati szempontból kiemelt fontossággal bír a nemzetközi kiküldetés és így a tudás megszerzésének eredményessége, adaptálhatósága, a tapasztalat integrálása a szervezetbe (Szabó et al. 2017). A nemzetközi kiküldöttet más néven expatriótának nevezzük, akit a saját országában lévő vállalkozás foglalkoztat és a munkáltatója által megtervezett program által külföldi munkavégzésben vesz részt egy meghatározott ideig, mely után a vállalat tervezi az ő visszatérését és hosszútávú foglalkoztatását (Ang et al. 2003). Az ilyen kiutazás komoly tervezést igényel, melyet a karriermenedzsment-rendszer és a karrierút megtervezésének oldaláról szemléltet a 4. ábra. A karriermenedzsment-rendszerhez számos alfunkció kapcsolódik, de ha a folyamatot megfordítjuk, akkor nemzetközi munkavégzéshez kötött globális karriermendzsmenthez csatolhatjuk a funkciók rendszerét. A folyamat így átláthatóbbá válik, ami munkavállalói szempont is. A karrier azért válik globálissá, mert országhatárokon átívelő munkavégzésről beszélhetünk.

Poór és szerzőtársai (2018) benchmarkingra épülő kutatásában a képzés-fejlesztést és a tehetséggondozást mint kritikus HR területeket említi. De ide tartozik az alkalmazotti kommunikáció és a teljesítménymenedzsmentben alkalmazott eszközök is.

4. ábra. Globális karriermenedzsment funkciók

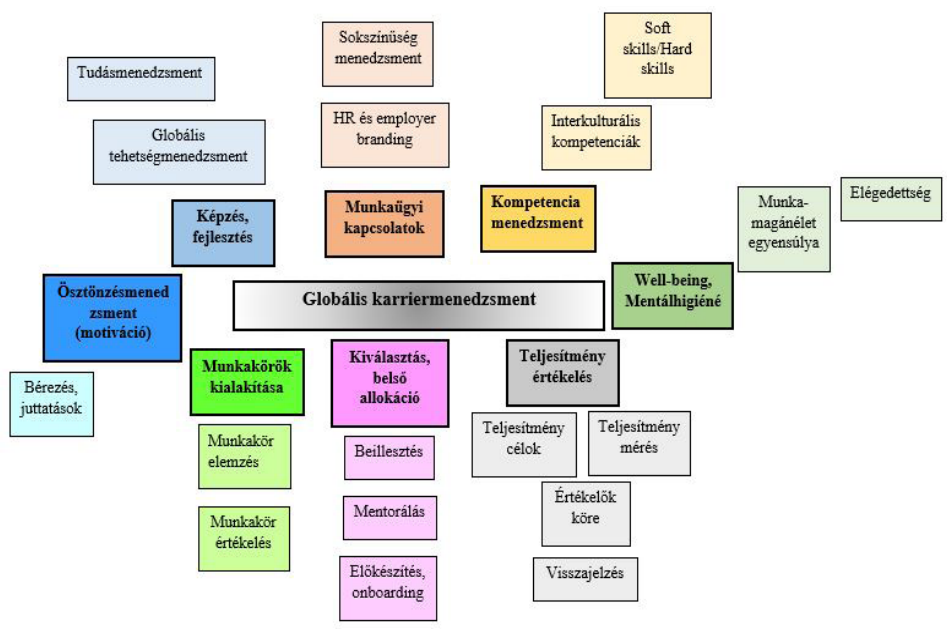

Forrás: Saját szerkesztés 


\section{TEMATIKUS TANULMÁNYOK - Emberierőforrás-menedzsment napjainkban}

A külföldi munkatapasztalat megszerzésének tervezésében a kezdeti lépések között szerepel a megfelelő munkaerő kiválasztása. A folyamatban lényegi segítséget nyújt a munkakör-specifikus kompetencialista, ami feltérképezi a jelölt tulajdonságait, képességeit. A szervezeten belül dolgozók munkavégzéshez kapcsolt értékrendje változó lehet, ami miatt fontossá válik egy olyan egységes eszköz, amely mindenki számára érthetően alkalmazza a feladatokat, felelősségi köröket, elvárásokat, mind munkafeladatok, mind kompetenciák terén. Az egyértelmú, átlátható, tisztázott és megfelelően definiált munkakörök elősegítik ezt a folyamatot, mely kapcsán szintén fejlődést láthatunk. A munkaköri leírásban szereplő információkat hatékonyan szemléltetheti a PaTeNtC JD5TC térbeli munkaköri leírás (Pató Gáborné - Illés 2018), ami a gamifikáció vagy más néven játékosítás eszközével élve, térbeliségének segítségével élmény alapúan mutatja a munkaköri leírás tartalmi, technikai és személyi specifikációit, illetve az ezek közötti összefüggéseket és viszonyrendszereket.

A vállalatok tehetségvonzó brandjének programjai közé sorolható a külföldi munkavállalás lehetősége. A fiatalabb generációk számára vonzó a külföldi tapasztalatszerzés ilyen lehetősége a karrierút elképzelése során. Csehné és munkatársai (2017) által megkérdezett gazdasági szakos egyetemi hallgatók több mint 50\%-ánál a munkaerőpiaci elvárások között szerepelt a multinacionális vállalatok által nyújtott karrier alternatíva.

A kompetenciák megléte munkaadói oldalról egy komplex igény és elvárás, munkavállalói szemszögből viszont elengedhetetlen a hatékony munkavégzéshez. Veszélyforrást okoz, ha a kiküldetésnél a kemény kompetenciákra esik nagyobb hangsúly és a soft skillek kisebb jelentőségben vannak jelen. Ezek a puha kompetenciák különösen nagy szereppel bírnak, jelentőségük megkérdőjelezhetetlen. Rudnák és Garamvölgyi (2016) több interkulturális kompetenciát is megnevez tanulmányában, melyek közé sorolható a teljesség igénye nélkül a nyelvi készségek megléte, a türelem és tisztelet, a pontos öntudat, interperszonális kompetenciák és a bizonytalanság toleranciája.

A másik kiemelt tényező a mentorálás és a mentor jelenléte a beillesztési folyamatban. A mentori munka és gyakorlat korrelál a megelégedettséggel, költséghatékonysággal és a munkavállalói lojalitással is (Bencsik et al. 2014, Csehné - Hajós 2014). A beillesztés a legtöbb esetben valamilyen információ vagy tudásátadási tevékenységre épül, melynek informális és formális szakasza is megkülönböztethető (Kozák 2014, Móré 2011).

A mentálhigiéné, a well-being egyik szelete sokszor kerül a fontossági sorrend végére, pedig a sorozatos negatív stressz okozta kiégés (burn out) elkerülhető a megfelelő felkészüléssel. A kiküldetés alatt számos alkalommal érezhető a kulturális sokk okozta idegesség, a bizonytalanság, az információ hiányában elvárt döntések miatt kialakuló stresszfaktor. A megfelelő mentálhigiénés felkészítés, a munka-magánélet egyensúlyára törekvő rendelkezések, a rendszeres visszajelzés és kapcsolat- 


\section{TEMATIKUS TANULMÁNYOK - Emberierőforrás-menedzsment napjainkban}

tartás a kiküldöttel elősegítheti a folyamat egy másik oldalról (a munkavállaló oldaláról) történő támogatását.

A teljesítményelvárások meghatározása elengedhetetlen elem, a teljesítmény mint egy indikátor jelenik meg a szervezetben. A vezetés számára a teljesítményértékelés (és az e köré épített teljesítménymenedzsment) egy olyan eszköz, amely a teljesítmény mérését, a teljesítmény célokat, a visszacsatolást és az elismerést használva elősegíti a munkavállalóban lévő potenciál növelését és a motiváció hosszútávú fenntartását (Gergely 2016). A kiküldetés folyamata alatt (a globális karrier létrejöttét illetően) további kérdéseket vet fel az értékelők körének kialakítása. Az expatrióta munkavégzését a fogadó országban látják leginkább, de az ott megszerzett tudás és a tapasztalatok adaptációja csak a visszaérkezést követően válik majd mérhetővé.

Elton Mayo és a Hawthorni kísérletek óta a tudomány is jelentőséget tulajdonít a munkahelyi elégedettség érzésének. Elégedettséget okoz, ha a vezetőknek jelezhetőek az igények és az elégedettséget okozó tényezők, továbbá a teljesítmény is annál hamarabb közeledik az elvárthoz (vagy elvártnál magasabbhoz), minél magasabbá válik a megelégedettségi szintje a munkavállalónak (Juhász 2016). Az adott és kapott visszajelzés mindkét fél által elfogadott módja a szervezeti légkört is pozitív irányba befolyásolja.

A szakirodalom által megfogalmazottakat összegezve, a létrejövő globális karrier alatt értjük a vállalattól egy másik országba, tudásgyarapítás vagy -szerzés céljából kiküldött munkavállaló karrierútját, melynek komplexitása miatt több HR funkció együttes fennállása és hatékony működése szükséges.

\section{Összegzés}

A karriertervezés szerepére az utóbbi évtizedekben egyre több figyelem hárult. A tudatos tervezés által könnyebben elérhetővé válnak az egyéni karriercélok és az egyén elegendő információt kap az őt körülvevő munkaerőpiac körülményeiről. A karriermenedzsment-rendszer jelenléte több szempontból is hasznos. Egyik oldalról a munkáltatónak, mert tudatosan tervezhet a jelenlévő munkaerő-állománynyal, utánpótlást nevelhet ki, elősegítheti a lojalitás, a szervezethez való tartozás érzését. A munkavállaló számára pedig azért is járhat előnnyel a folyamat, mert öszszekötheti egyéni karriercéljait a szervezetével, a karrierjéhez segítséget kap a vállalattól, fejlesztést tesz lehetővé és folyamatos visszacsatolásban részesülhet. Az egyéni és szervezeti célok egyidejű teljesülése okoz elégedettséget mindkét félnek és ez vetíti elő a karriermenedzsment-rendszer hosszútávú sikerességét és hatékonyságát.

A globális karriermenedzsmentben a hagyományos és az újabb HR funkciók is szerepet kapnak, csupán más mélységben. Ha a funkciók valamilyen sorrendiségé- 


\section{TEMATIKUS TANULMÁNYOK - Emberierőforrás-menedzsment napjainkban}

ben gondolkozunk, akkor nyilvánvalóvá válik, hogy egy kiküldetés során a humán erőforrás menedzselésének más tevékenységterületei kerülnek előtérbe és kapnak nagyobb figyelmet, mint egy szervezeti karriertervezés esetében. A kiküldetésre legalkalmasabb egyének kiválasztása, akár már a munkahelyre történő bekerülést követően is megtörténhet, hiszen a felkészítés időigényes folyamat, különösen ha több hónapos, vagy éves kiküldetésről beszélünk. A felkészítés alatt nagy jelentősége van a mentornak, ám a fogadóországban szintén jelenlévő mentor még inkább garantálhatja a gyors beilleszkedést és a teljesítmény hamarabbi növekedését. A kiküldetés alatt leginkább felmerülő kulcskompetenciák felismerése és a hiányuk, vagy nem megfelelő szintjük esetében történő fejlesztés talán a legösszetettebb és legtöbb erőforrást igénylő tevékenység.

A vállalatok számára előnyös a kiküldetésben sikeresen helytálló tehetségek megtartása. De emellett magas szakmai és interperszonális tapasztalattal és képességekkel rendelkező szakembereket képeznek, növekszik a lojalitás a szervezet iránt a kiszámítható karrierút jelenléte miatt. A munkavállalói célok és érdekek ilyen irányú összekapcsolása teszi lehetővé a mindkét oldal számára nyereséges globális karriermendzsment-rendszer kialakítását és hatékony működtetését.

\section{Irodalom}

Ang, S. - Dyne, L. V. - Begley, T. M. (2003): The employment relationship of foreign workers versus local employees: a field study of organizational justice, job satisfaction, performance, and OCB. Journal of Organizational Behaviour. 24(5): 561-583. DOI: 10.1002/job.202

Baruch, Y. (2006): Career development in organizations and beyond: Balancing traditional and contemporary viewpoints. Human Resource Management Review. 16(2): 125-138.

Batizi D. (2017): Újfajta karrierutak. A változatos és a határvonalak nélküli pályafutási modellek. Tér, Gazdaság, Ember IV. évf. 1: 7-23.

Bencsik A. - Juhász T. - Machova R. (2014): Mentoring Practice on behalf of knowledge sharing in the light of Education. Acta Polytechnica Hungarica, 11: (9): 95-114.

Berde Cs. (2015): Vezetési feladatok. In: Bácsné Bába É. - Berde Cs. - Dajnoki K. (szerk.): A vezetés alapjai. Debrecen, Debreceni Egyetem, 5-71.

Bokor A. - Fejér P. - Frisch A. - Ladányi V. - Szabadi H. (2006a): Karriermenedzsment Magyarországon - HR vezetők nézőpontja. Munkaügyi Szemle. 50. évf. I. rész, 10: 15-18. 


\section{TEMATIKUS TANULMÁNYOK - Emberierőforrás-menedzsment napjainkban}

Bokor A. - Fejér P. - Frisch A. - Ladányi V. - Szabadi H. (2006b): Karriermenedzsment Magyarországon - HR vezetők nézőpontja. Munkaügyi Szemle. 50. évf. III. rész, 12: 11-14.

Clarke, M. (2013): The organizational career: not dead but in need of redefinition. The International Journal of Human Resource Management, 24(4): 684-703.

Csehné Papp I. - Hajós L. (2014): Education and working life in Hungary. Acta Technica Corviniensis - Bulletin of Engineering. 2: 105-110.

Csehné Papp I. - Varga E. - Szabó K. - Szira Z. - Hajós L. (2017): The appearance of a new generation on the labour market. Annals of Faculty Of Engineering Hunedoara - International Journal of Engineering 15(1): 123-130.

Dajnoki K. (2014): Helyet mindenkinek! Fogyatékos, illetve megváltozott munkaképességű munkavállalók HR-sajátosságainak feltárása az Észak-alföldi régióban. Egyesület Közép-Európa Kutatására, Szeged.

Dajnoki K. - Héder M. (2017): „Új szelek fújnak” - a HR válasza a globalizáció és a változás kihívásaira. Hadtudomány. A Magyar Hadtudományi Társaság folyóirata, 2017. évi elektronikus lapszám (27). 84-93. DOI 10.17047/HADTUD. 2017.27. E.84., http://mhtt.eu/hadtudomany/2017/2017_elektronikus/dajnoki.pdf (letöltés ideje: 2019.11.10.)

Dessler, G. - Cole, N. D. (2008): Human Resources Management in Canada. 10th edition. Pearson Education in Canada, Toronto, Ontario.

DGS Global (2009): A HR Magyarországon: az Országos HR Benchmark felmérés kutatási összefoglalója. http://www.dgsglobal.hu (letöltés ideje: 2020. 03.16.)

Erdei P. - Fenyves V. - Dajnoki K. (2017): A munkahelyi elköteleződés felmérése és fejlesztési célok meghatározása. Taylor Gazdálkodás- és szervezéstudományi folyóirat. A Virtuális Intézet Közép-Európa Kutatására Közleményei. IX. évf. 2(28): 107-113.

Fajcikova, A. - Urbancova, H. - Kucirkova, L. (2018): Decisive Factors of talent management implementation in Czech organizations. Journal of Efficiency and Responsibility. Education and Science. 11(1): 9-15.

Fayol, H. (1916): Administration Industrielle et Generale. Donud, Paris.

Gergely É. (2016): A teljesítménymenedzsment funkcionális jellege. International Journal of Engineering and Management Sciences / Műszaki és Menedzsment Tudományi Közlemények 1(1): 1-14.

Guan, Y. - Zhou, W. - Ye, L. - Jiang, P. - Zhou, Y. (2015): Perceived organizational career management and career adaptability as predictors of success and turnover intention among Chinese employees. Journal of Vocational Behaviour, 88: 230237. 
Gulyás L. - Turcsányi E. (2018): A humán erőforrás menedzsment funkciók fejlődése 2. rész. A „bürokrata” szakasz jellemzői = Development of function of human resource management part II. Közép-Európai Közlemények, 11(2): 155-159. https://ojs.bibl.u-szeged.hu/index.php/vikekkek/article/view/12495 (letöltés ideje: 2020. 03. 16.)

Hajós L. - Gősi M. (2008): Emberi erőforrás gazdálkodás (EEG). In: Hajós L. - Berde Cs. (szerk.): Emberi erőforrás gazdálkodás. Szaktudás Kiadó Ház, Budapest, 1823.

Istók N. (2019): Több mint hűség. Az elköteleződés nem az évek számában mérhető. http://hrpwr.hu/megtartas/cikk/az_elkotelezodes_nem_az_evek_szamaban_ merheto (letöltés ideje: 2019.11. 10.)

Juhász Cs. (2016): Elvárások és elégedettség. Taylor. Gazdálkodás- és szervezéstudományi folyóirat. A Virtuális Intézet Közép-Európa Kutatására Közleményei 24(3): 58-64.

Klein S. (2012): Vezetés- és szervezetpszichológia. SHL könyvek, Budapest.

Koncz K. (2013): Karriermenedzsment. Budapest, Budapesti Corvinus Egyetem.

Kozák A. (2014): A munkahelyi beillesztés gyakorlata egy coloradoi székhelyű vállalatnál. Taylor Gazdálkodás- és szervezéstudományi folyóirat, 168-177.

Krajcsák Z. (2018): Az alkalmazotti elkötelezettség relatív fontossága a munka megváltozó világában. Vezetéstudomány 49(2): 38-44.

Lewis, S. - Arnold, J. (2012): Organisational career management in the UK retail and buying and merchandising community. International Journal of Retail \& Distribution Management. 40(6): 451-470.

Mándi A. (2018): Job hopping és a tudásvállalatok. Munkaügyi Szemle, 61(1): 41-46.

Móré M. (2011): Te csak beszélj, és könnyen beilleszkedem. A beillesztés kommunikációs összefüggései. VIKEK Közlemények, 2011/1-2: 43-51.

Pató Gáborné Sz. B. - Illés K. (2018): Az emberközpontú munkaköri leírás. Hadtudomány. A Magyar Hadtudományi Társaság folyóirata. 28(2): 107-117. DOI 10.17047/HADTUD.2018.28.2.107

Poór J. - Balogh G. - Bálint B. - Dobay P. - Kollár Cs. (2017): Integrált és integráló EEm-rendszerek és eszközök. 359-396. In: Karoliny M. - Poór J. (szerk.): Emberi erőforrás menedzsment kézikönyv. Rendszerek és alkalmazások. Wolters Kluwer, Budapest.

Poór J. - Juhász T. - Szabó K. - Kovács I. É. - Karoliny M. (2018): A külföldi tulajdonú vállalatok emberi erőforrás menedzselésének jellegzetességei és sajátos kontingenciafaktorai Kelet-Közép-Európában. Vezetéstudomány / Budapest Management Review. XLIX. évf. 1: 40-52. 


\section{TEMATIKUS TANULMÁNYOK - Emberierőforrás-menedzsment napjainkban}

Rudnák I. - Garamvölgyi J. (2016): Correlations between intercultural competence, cultural intelligence and culture shock. In: Takácsné György K. (szerk.): Innovációs kihívások és lehetőségek 2014-2020 között: XV. Nemzetközi Tudományos Napok. 485-494.

Szabó K. - Tanyik G. E. - Csernák J. (2017): Az Y generáció és a nemzetközi kiküldetések. Acta Carolus Robertus, 2017. 7(2): 181-202.

Szabó M. - Berde Cs. (2007): Esélyegyenlőség az emberi erőforrás menedzsmentben. In: Berde Cs. - Dajnoki K. (szerk.): Esélyegyenlőségi emberi erőforrás menedzsment. Debreceni Campus Kht., Debrecen, 24-38.

Taylor, F. W. (1911): The Principles of Scientific Management. Harper and Brothers. New York.

The Current State of Performance Management and Career Development (2010) http://www.aon.com/attachments/thought-leadership/Hewitt_Survey_ Results_PerfMgmtCareerDevSV10.pdf (letöltés ideje: 2019.11.10.)

Veresné Somosi M. (2017): A szervezeti képességépítés néhány sajátossága. Taylor Gazdálkodás- és szervezéstudományi folyóirat. A Virtuális Intézet Közép-Európa Kutatására Közleményei. IX. évf. 2(28): 152-160. 